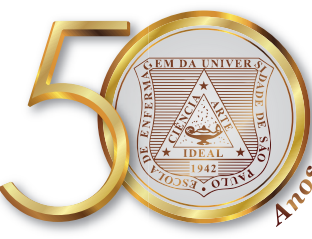

\title{
Association of self-efficacy of parents/caregivers with childhood asthma control parameters*
}

\author{
Associação da autoeficácia de pais/cuidadores com os parâmetros de controle da asma infantil \\ Asociación de la autoeficacia de padres/cuidadores con los parámetros de control del asma infantil
}

Ana Lúcia Araújo Gomes ${ }^{1}$, Kamila Ferreira Lima ${ }^{1}$, Elizamar Regina da Rocha Mendes ${ }^{1}$, Emanuella Silva Joventino ${ }^{2}$, Mariana $^{1}$ Cavalcante Martins ${ }^{1}$, Paulo César de Almeida ${ }^{3}$, Lorena Barbosa Ximenes ${ }^{1}$

How to cite this article:

Gomes ALA, Lima KF, Mendes ERR, Joventino ES, Martins MC, Almeida PC, et al. Association of self-efficacy of parents/caregivers with childhood asthma control parameters. Rev Esc Enferm USP. 2017;51:e03282. DOI: http://dx.doi.org/10.1590/S1980-220X2017008003282

${ }^{*}$ Extracted from the thesis 'Tradução, adaptação e validação da escala Self-efficacy and their child's level of asthma control: versão brasileira",

Programa de Pós-Graduação em Enfermagem, Universidade Federal do Ceará, 2015.

${ }^{1}$ Universidade Federal do Ceará, Fortaleza, CE, Brazil.

${ }^{2}$ Universidade da Integração Internacional da Lusofonia Afro-Brasileira, Redenção, CE, Brazil.

${ }^{3}$ Universidade Estadual do Ceará,

Fortaleza, CE, Brazil.

\begin{abstract}
Objective: To verify the association between the self-efficacy of parents/caregivers and control parameters of childhood asthma. Method: Cross-sectional study with parents/caregivers of asthmatic children. Data were collected through a sociodemographic questionnaire and the Self-efficacy and their child's level of asthma control scale: Brazilian version. Results: Participation of 216 parents/caregivers in the study. There was a statistically significant association between self-efficacy scores and the following variables: unscheduled physician visit $(\mathrm{p}=0.001)$, visit to emergency department $(\mathrm{p}<0.001)$, hospital stays in the previous 12 months $(\mathrm{p}=0.005)$, physical activity limitation $(\mathrm{p}=0.003)$, school days missed $(\mathrm{p}<0.001)$, impaired sleep $(\mathrm{p}<0.001)$, ability to differentiate crisis medication from control medication $(p=0.024)$, use of spacer $(p=0.001)$, performing oral hygiene after use of inhaled corticosteroids ( $p=0.003$ ), and knowledge of medication gratuity $(p=0.004)$. Conclusion: A significant relationship of the self-efficacy of parents/caregivers of asthmatic children with control parameters and training on the necessary skills to reach this control was demonstrated in the study.
\end{abstract}

DESCRIPTORS

Child; Asthma; Caregivers; Self Efficacy; Pediatric Nursing.
Corresponding author:

Kamila Ferreira Lima

Rua Alexandre Baraúna, 1115 - Rodolfo Teófilo CEP 60416-000 - Fortaleza, Ceará, Brazil

limakamila@yahoo.com.br
Received: 02/21/2017

Approved: 08/17/2017 


\section{INTRODUCTION}

Asthma is a potentially serious chronic disease affecting more than 300 million people worldwide. However, $60 \%$ of these are children, a population in which prevalence is increasing particularly in developing countries ${ }^{(1-2)}$.

Along a one-year period (from 2014 to 2015), were registered 129,626 hospitalizations for asthma in Brazil, 63\% of which corresponded to the age group of children under 14 years. The Northeast region had the highest incidence of hospitalizations in this period $(55,876$ cases), with a higher incidence among children aged 1 to 4 years (16,181 cases). In the state of Ceará, there were 6,432 records, and the city of Fortaleza accounted for $41 \%(2,675)$ of these cases $^{(3)}$.

Asthma hospital stays usually result from inadequate control of the illness due to innumerable factors, namely: absence of continuous outpatient follow-up; discontinuation of prophylactic medication; preventive measures in the home environment that are inadequate to the socioeconomic and cultural reality of families; lack of education and family support that enable the control and management of this aggravation ${ }^{(4)}$.

Asthma control can be influenced by psychological, therapeutic, and environmental factors, among which behavioral factors, with emphasis on self-efficacy ${ }^{(2)}$. This is individuals' belief in their ability to perform actions that will influence the events affecting their lives, determining how people feel, think, motivate themselves and behave in the face of obstacles and adverse experiences ${ }^{(5)}$.

Thus, self-efficacy can be considered a determining factor for healthy behavior promotion. A study conducted in Iran with 172 mothers of asthmatic children found an association between higher levels of self-efficacy with better asthma control and higher rates of quality of life ${ }^{(6)}$. This concept is considered an important predictor of therapeutic adherence and a determinant of health behavior ${ }^{(7)}$.

Recognizing the importance of behaviors of parents/caregivers for the management and control of childhood asthma, the Self-efficacy and their child's level of asthma control scale was translated and adapted to Brazil ${ }^{(8)}$. It was developed based on the theoretical reference of self-efficacy ${ }^{(5)}$ and clinical guidelines regarding asthma control parameters.

The scale is aimed at parents/caregivers of children with asthma by addressing two domains; expectations of efficacy and expectations of results. The first domain refers to the confidence in recognizing asthma triggers in the child, understanding health professionals' orientations and the use of treatment devices such as inhalers, spacers, and peak flow meters. The expectations of results seek to encourage the belief that a good management of children's asthma would result in fewer visits to the physician, fewer visits to urgency and emergency services, fewer hospital stays and fewer days of school days $\operatorname{missed}^{(8)}$.

Thus, the self-efficacy in controlling infant asthma contributes to a better management of asthma, results in a reduction of symptoms and exacerbations ${ }^{(1,9)}$ and collaborates to reach the control parameters in order to achieve controlled asthma status $^{(10)}$. To this end, the understanding that this chronic condition is controllable increases the confidence about living with this state of health and maintaining a better quality of life $\mathrm{e}^{(11)}$.
Therefore, in view of the chronicity and prevalence of childhood asthma, its morbidity and interference in the quality of life of affected individuals and their families, and the complexity of its management and control, the aim of this study was to verify the association of the self-efficacy of parents/caregivers with control parameters of childhood asthma.

\section{METHOD}

A cross-sectional study, based on the association of self-efficacy with control parameters and the skill training for childhood asthma control. It was conducted in three Primary Health Care Units (Portuguese acronym: UAPS Unidades de Atenção Primária à Saúde) located in the most populous neighborhood of the fifth largest capital of Brazil, the city of Fortaleza (state of Ceará) that has more than 50,000 people living in precarious health conditions ${ }^{(12)}$.

Sampling was done for convenience, and 216 parents/caregivers of children with asthma participated in the study. They were regularly followed while receiving outpatient care in the Program for Care of Children with Asthma (Portuguese acronym: PROAICA - Programa de Atenção à Criança com Asma) in the aforementioned health units with established medical diagnosis of asthma, and prescribed inhalation therapy (with or without use of a spacer). Parents/caregivers with communication barriers and those who cared for children diagnosed with asthma associated with other pulmonary pathologies that made asthma difficult to control were excluded.

Data were collected by a nurse and two community health agents (Portuguese acronym: ACS - Agentes Comunitárias de Saúde), who were duly trained for six months (from August 2014 to January 2015) in two stages. In the first stage, was established the eligibility of 279 potential participants through the review of medical records and Form A. This is an instrument recommended by the Ministry of Health and completed by the ACS. The second stage involved home visits to potential participants. Those who agreed to participate in the study were asked to sign the Informed Consent form.

The choice for home visits to the previously selected parents/caregivers had the purpose of guaranteeing a greater reach of families of children with asthma. In total, 216 visits were made, in which were applied the sociodemographic questionnaire and the Self-efficacy and their child's level of asthma control scale: Brazilian version.

The Self-efficacy and their child's level of asthma control scale: Brazilian version allows the evaluation of the self-efficacy of parents/caregivers in the control of childhood asthma. It was translated and validated with Content Validity Coefficient (CVC) of 0.88 and Cronbach's alpha of 0.92. It has 16 items distributed in two domains (expectations of efficacy and expectation of result of parents/caregivers regarding control of their children's asthma). The response pattern varies on a five-point Likert scale (ranging from 'totally agree' to 'totally disagree' with a neutral point), and total scores range from 17 to 85 points, as follows: 17-57 points are considered low self-efficacy; 58-67 points are moderate self-efficacy; and 68-85 points are high self-efficacy. The higher the score, the greater the confidence in the management and control of asthma by parents/caregivers of asthmatic children ${ }^{(8)}$. 
The parameters considered to establish the control levels of childhood asthma were the appearance of symptoms requiring use of relief medication and culminating in limitation of physical activities and intensity of airflow limitation measured from: daytime symptoms, limitation of activities, nocturnal symptoms/awakenings, need for relief medication, and pulmonary function ${ }^{(10)}$. The status of controlled asthma also depends on good management and administration for the development of skills and competences ${ }^{(1)}$.

Data were analyzed in the Statistical Package for the Social Sciences - SPSS (version 20.0). Descriptive and inferential statistics were used through the chi-square and maximum likelihood tests. The significance level was set at $5 \%(\mathrm{p}<0.05)$, and $95 \%$ confidence interval.

The exploratory analysis (absolute and relative frequencies, means and standard deviations) enabled comparisons and associations of the statistical variables of interest. The tabular representation allowed a quick, concise and clarifying visual communication of the obtained results.

Regarding ethical procedures, national norms of ethics in research involving human beings were respected in all the stages of this study in accordance with Resolution $466 / 12$ of the National Health Council ${ }^{(13)}$. Data collection was initiated only after approval of the research project by the Research Ethics Committee of the institutions involved under number 562.687/2014.

\section{RESULTS}

The study had participation of 216 parents/caregivers. From the sum of the scale of interviewed parents/caregivers, was found a variation from 58 to 85 points. Note that $47.7 \%$ ( $n=103$ ) had 67-point scores on the scale. The lowest score was 58 points, demonstrating two levels of self-efficacy: moderate and high. Thus, were made associations with parameters of asthma control, skill training for asthma control, and with levels of self-efficacy presented by parents/caregivers.

Table 1 shows the description of the association between scale scores and variables of asthma control parameters. There were statistically significant associations between self-efficacy scores and the following variables: unscheduled physician visit ( $\mathrm{p}=0.001)$, visits to emergency department $(p<0.001)$, hospital stays in the previous 12 months $(p=0.005)$, physical activity limitation $(p=0.003)$, school days missed $(p<0.001)$ and impaired sleep $(p<0.001)$.

The association between the scale scores and variables of skill training for asthma control in children was analyzed, as shown in Table 2. Thus, the self-efficacy of parents/caregivers in controlling children's asthma can be influenced by the following variables: ability to differentiate crisis medication from control medication $(\mathrm{p}=0.024)$, use of spacer $(\mathrm{p}=0.001)$, performing oral hygiene after use of inhaled corticosteroids $(\mathrm{p}=0.003)$ and knowledge about medication gratuity $(\mathrm{p}=0.004)$.

Table 1 - Association between scores of the Self-efficacy and their child's level of asthma control scale: Brazilian version and variables of asthma control parameters in relation to the previous 12 months - Fortaleza, Ceará, Brazil, 2015.

\begin{tabular}{|c|c|c|c|c|c|c|}
\hline \multirow[t]{2}{*}{ Variable } & \multicolumn{2}{|c|}{$\begin{array}{c}\text { Moderate } \\
\text { (58-67 points) }\end{array}$} & \multicolumn{2}{|c|}{$\begin{array}{c}\text { High } \\
\text { (68-85 points) }\end{array}$} & \multirow[t]{2}{*}{$x^{a^{*}}$} & \multirow{2}{*}{$\mathbf{p}$} \\
\hline & $\mathbf{N}$ & $\%$ & $\mathbf{N}$ & $\%$ & & \\
\hline Unscheduled physician visit $(n=193)$ & & & & & $13.950^{\mathrm{a}}$ & 0.001 \\
\hline None & 94 & 69.1 & 42 & 30.9 & & \\
\hline 1 to 2 & 12 & 41.4 & 17 & 58.6 & & \\
\hline 3 or more & 11 & 39.3 & 17 & 60.7 & & \\
\hline Visits to emergency department $(n=202)$ & & & & & $15.896^{\mathrm{a}}$ & $<0.001$ \\
\hline None & 101 & 70.6 & 42 & 29.4 & & \\
\hline 1 a 2 & 12 & 41.4 & 17 & 58.6 & & \\
\hline 3 or more & 11 & 40.0 & 18 & 60.0 & & \\
\hline Hospital stays $(n=203)$ & & & & & $7.926^{\mathrm{a}}$ & 0.005 \\
\hline None & 115 & 65.3 & 61 & 34.7 & & \\
\hline 1 to 4 & 10 & 37.0 & 17 & 63.0 & & \\
\hline Physical activity limitation $(n=208)$ & & & & & $13.737^{\mathrm{a}}$ & 0.003 \\
\hline Often & 3 & 21.4 & 11 & 78.6 & & \\
\hline Sometimes & 10 & 50.0 & 10 & 50.0 & & \\
\hline Hardly ever & 28 & 65.1 & 15 & 34.9 & & \\
\hline Never & 90 & 68.7 & 41 & 31.3 & & \\
\hline School days missed $(n=203)$ & & & & & $26.640^{\mathrm{a}}$ & $<0.001$ \\
\hline Often & 3 & 20.0 & 12 & 80.0 & & \\
\hline Sometimes & 10 & 52.6 & 9 & 47.4 & & \\
\hline Hardly ever & 18 & 56.2 & 14 & 43.8 & & \\
\hline Never & 95 & 73.6 & 34 & 26.4 & & \\
\hline Not in school age & 2 & 25.0 & 6 & 75.0 & & \\
\hline Impaired sleep $(n=211)$ & & & & & $26.263^{\mathrm{a}}$ & $<0.001$ \\
\hline Yes & 7 & 22.6 & 24 & 77.4 & & \\
\hline No & 127 & 70.6 & 53 & 29.4 & & \\
\hline
\end{tabular}

* Chi-square.

Source: Elaborated by the authors. 
Table 2 - Association between scores of the Self-efficacy and their child's level of asthma control scale: Brazilian version and variables of skill training for asthma control - Fortaleza, Ceará, Brazil, 2015.

\begin{tabular}{|c|c|c|c|c|c|c|}
\hline \multirow[t]{2}{*}{ Variable } & \multicolumn{2}{|c|}{$\begin{array}{c}\text { Moderate } \\
(58-67)\end{array}$} & \multicolumn{2}{|c|}{$\begin{array}{c}\text { High } \\
(68-85)\end{array}$} & \multirow[t]{2}{*}{$x^{\mathrm{a}^{*}}$} & \multirow[t]{2}{*}{$\mathbf{P}$} \\
\hline & $\mathbf{N}$ & $\%$ & $\mathbf{N}$ & $\%$ & & \\
\hline Ability to differentiate crisis medication from control medication $(n=153)$ & & & & & $5.114^{\mathrm{a}}$ & 0.024 \\
\hline Yes & 78 & 67.8 & 37 & 32.2 & & \\
\hline No & 18 & 47.4 & 20 & 52.6 & & \\
\hline Use of spacer $(n=191)$ & & & & & $11.449^{\mathrm{a}}$ & 0.001 \\
\hline Yes & 16 & 39.0 & 25 & 61.0 & & \\
\hline No & 2 & 68.0 & 48 & 32.0 & & \\
\hline Scalds spacer $(n=48)$ & & & & & $485^{\mathrm{a}}$ & 0.486 \\
\hline Yes & 3 & 30.0 & 7 & 70.0 & & \\
\hline No & 16 & 42.1 & 22 & 57.9 & & \\
\hline Performs oral hygiene after inhaled corticosteroid $(n=147)$ & & & & & $8.937^{\mathrm{a}}$ & 0.003 \\
\hline Yes & 82 & 65.6 & 43 & 34.4 & & \\
\hline No & 7 & 31.8 & 15 & 68.2 & & \\
\hline Received information on control of asthma symptoms $(n=147)$ & & & & & $2.583^{\mathrm{a}}$ & 0.108 \\
\hline Yes & 128 & 64.3 & 71 & 35.7 & & \\
\hline No & 6 & 42.9 & 8 & 57.1 & & \\
\hline Knowledge about medication gratuity $(n=213)$ & & & & & $8.080^{\mathrm{a}}$ & 0.004 \\
\hline Yes & 132 & 64.3 & 67 & 33.7 & & \\
\hline No & 4 & 42.9 & 10 & 71.4 & & \\
\hline
\end{tabular}

* Chi-square.

Source: Elaborated by the authors.

\section{DISCUSSION}

The best self-efficacy scores presented by parents/ caregivers of asthmatic children may favor the remission of presented symptoms ${ }^{(14)}$. Therefore, in the present study was demonstrated the contribution of the moderate or high self-efficacy of parents/caregivers for achieving satisfactory parameters of childhood asthma control, namely: unscheduled physician visits, no visits to emergency departments, absence of hospital stays, no physical activity limitation, no school days missed, and no impaired sleep.

Uncontrolled asthma conditions result in search for emergency services and hospitalizations ${ }^{(15)}$. Thus, a study conducted in North Carolina (USA) confirms the high number of physician visits and hospital stays for this cause in spite of guidelines for disease management, pharmacological treatment advances, and strong evidence of performance of control medication on asthma attacks ${ }^{(16)}$.

In addition, research has shown that disease control is not achieved in many asthmatic children because of the gap between the recommended and practiced care practices ${ }^{(17-18)}$. Therefore, parents' knowledge, attitudes and practices should be included in routine clinical care, as in the presence of asthma, these aspects express confidence regarding management and efficiency in the care process $^{(18)}$.

Positive experiences in child care favor greater perceived self-efficacy and may affect people's choices and performance, determining how they feel, think, motivate themselves and behave. Perceived self-efficacy has direct influence on choices by determining how much effort will be required from people and how long they will persist in the face of obstacles and aversive experiences ${ }^{(5)}$.

Regarding physical activity limitation, this variable had a significant relationship with scale scores, demonstrating the association of self-efficacy with improvement of care provided to children. Results from a meta-analysis state that physical activity in childhood may act as a protective factor for asthma attacks. Therefore, children and adolescents with low practice of physical activity tend to experience worsening of symptoms of the already established disease ${ }^{(19)}$.

It is known that many children with asthma avoid or are prevented by their parents from engaging in physical activity and participating in more strenuous play. These attitudes may distort or interfere in the assessment of asthma control parameters, which is based on symptoms in childhood, with limitations imposed by the disease and the need to use rescue medication. Careful assessment of the impact of asthma on daily activities of a child is important, including activities that require some kind of physical exertion ${ }^{(1)}$.

School days missed and impaired sleep are relevant aspects regarding self-efficacy in favorable management for asthma control in children. This finding converges with data from a study conducted in Miami-Dade (USA), which stated uncontrolled asthma as the leading cause of school days missed in the country ${ }^{(20)}$. In addition, another American study found that school-aged children with impaired sleep resulting from uncontrolled asthma had lower school performance and difficulty with keeping alert during classes ${ }^{(21)}$. It is worth to notice that sleep is a strong predictor of health promotion ${ }^{(22)}$.

In the present study, the development of skills to differentiate crisis medication from control medication, and the use of spacer are associated with better self-efficacy scores. The association of education with pharmacological treatment is fundamental in asthma management, and should be part of care for patients of any age, especially children ${ }^{(10)}$. 
Health professionals' guidance to parents and/or caregivers is important, and self-management support should be offered as a written action plan with regular reevaluation ${ }^{(21)}$. Thus, effective management of asthma requires the acquisition of knowledge, skills and confidence by people with this condition or caregivers in order to play an important role in the management of this condition, thus reducing morbidity and improving levels of control ${ }^{(1)}$.

Parents/caregivers of asthmatic children should have the necessary knowledge to prevent adverse effects. The most common are dysphonia, dental caries and oral candidiasis. Such effects may be caused by high dosage administration of inhaled corticosteroids, which generally occurs as a result of lack of efficacy in treatment management ${ }^{(23)}$. However, the potential risk can be minimized by using the spacer and performing oral hygiene after medication administration ${ }^{(10)}$.

The findings also indicated a significant association between knowledge about medication gratuity and self-efficacy in controlling childhood asthma. There were similar results in a study ${ }^{(24)}$ developed in Brazil that demonstrated a $33.57 \%$ decrease in hospitalization rates for asthma with the knowledge and access to free medication by the Popular Pharmacy program (beclomethasone and salbutamol). This represented a saving of $51 \%$ in financial expenses of the system with asthma-related hospitalizations.

The maximization of access to medication with guarantees of use according to an action plan associated to an adequate technique for use of inhalation devices is a primordial factor in the management of asthma exacerbations and prevention of severe episodes of the disease ${ }^{(24-25)}$.

The present cross-sectional study described the association between the studied variables. It did not allow the establishment of a cause and effect relationship, but allowed identifying the readiness with which high levels of self-efficacy can influence asthma control in a certain period of time. Hence the suggestion of conducting randomized experimental studies using the Self-efficacy and their child's level of asthma control scale: Brazilian version to evaluate interventions that aim to contribute to the control of childhood asthma.

\section{CONCLUSION}

The study evidences a significant relation of the self-efficacy of parents/caregivers of children with asthma with control parameters and training on necessary skills to reach this control. Thus, high levels of self-efficacy contribute directly to asthma control, and as a consequence, to the health promotion of these children and their families.

Based on the findings and considering the study objective, the conclusion is that control parameters of childhood asthma associated with the self-efficacy of parents/caregivers of asthmatic children were the following: no unscheduled physician visits, no visits to the emergency department, absence of hospital stays, no limitation of physical activity, no school days missed, and no impairment of sleep.

The aspects of skill training of parents/caregivers of asthmatic children associated with high levels of self-efficacy evidenced in the present study were the following: knowledge on the difference between crisis medication and control medication, use of the spacer, performance of oral hygiene after use of inhaled corticosteroids, and knowledge about gratuity of medication.

A limitation of the study was the sample loss $(n=63)$ throughout home visits due to characteristics of the visited community, such as frequent change of address, urban violence in the assigned territory and difficult access to the dune areas.

The role of nurses can substantially help families to raise their levels of self-efficacy from guidelines focused on skill training for the mastery of complexities for good asthma management in childhood. Therefore, during nursing consultations, the factors influencing treatment adherence can be identified, and children and their families can be involved in the health-disease process.

\section{RESUMO}

Objetivo: Verificar a associação entre autoeficácia dos pais/cuidadores e parâmetros de controle da asma na infância. Método: Estudo transversal com pais/cuidadores de crianças com asma. Os dados foram coletados por meio de questionário sociodemográfico e pela escala Self-efficacy and their child's level of asthma control: versão brasileira. Resultados: Participaram do estudo 216 pais/cuidadores. Foi encontrada associação estatisticamente significante entre os escores de autoeficácia e as seguintes variáveis: consulta médica não programada $(p=0,001)$, visita às emergências $(p<0,001)$, hospitalizações nos últimos 12 meses ( $p=0,005)$, limitação de atividade física $(\mathrm{p}=0,003)$, absenteísmo escolar $(\mathrm{p}<0,001)$, sono prejudicado $(\mathrm{p}<0,001)$, saber diferenciar medicação de crise da medicação de controle $(\mathrm{p}=0,024)$, uso de espaçador ( $\mathrm{p}=0,001)$, realiza higiene oral após o uso de corticoide inalatório ( $\mathrm{p}=0,003)$ e conhecimento da gratuidade da medicação $(p=0,004)$. Conclusão: $O$ estudo evidencia uma relação significativa da autoeficácia dos pais cuidadores de crianças com asma infantil com os parâmetros de controle e com a formação de competências necessárias para alcançar este controle.

\section{DESCRITORES}

Criança; Asma; Cuidadores; Autoeficácia; Enfermagem Pediátrica.

\section{RESUMEN}

Objetivo: Verificar la asociación entre la autoeficacia de padres/cuidadores y los parámetros de control del asma en la infancia. Método: Estudio transversal con padres/cuidadores de niños con asma. Los datos fueron recogidos mediante cuestionario sociodemográfico y por la escala Self-efficacy and their child's level of asthma control: versión brasileña. Resultados: Participaron en el estudio 216 padres/cuidadores. Fue encontrada asociación estadísticamente significativa entre los scores de autoeficacia y las siguientes variables: consulta médica no programada $(\mathrm{p}=0,001)$, visita a las emergencias $(\mathrm{p}<0,001)$, hospitalizaciones los últimos 12 meses ( $\mathrm{p}=0,005)$, limitación de actividad física $(p=0,003)$, absentismo escolar $(p<0,001)$, sueño perjudicado $(p<0,001)$, saber diferenciar medicación de crisis de la medicación de control $(\mathrm{p}=0,024)$, uso de espaciador $(\mathrm{p}=0,001)$, realiza higiene oral tras el uso de corticoide inhalado $(\mathrm{p}=0,003)$ y conocimiento de la gratuidad de la medicación $(p=0,004)$. Conclusión: El estudio evidencia una relación significativa de la autoeficacia de los padres cuidadores de niños con asma infantil con los parámetros de control y con la formación de competencias necesarias para alcanzar este control.

\section{DESCRIPTORES}

Niño; Asma; Cuidadores; Autoeficacia; Enfermería Pediátrica. 


\section{REFERENCES}

1. Global Initiative for Asthma. Pocket guide for health professionals, updated 2015. [Internet]. Bethesda: GINA; 2015 [cited 2016 June 9]. Available from: http://ginasthma.org/wp-content/uploads/2016/01/GINA_Pocket_2015.pdf

2. Global Asthma Network. The Global Asthma Report 2014 [Internet]. New Zealand; 2014 [cited 2016 June 9]. Available from: http://www. globalasthmareport.org/resources/Global_Asthma_Report_2014.pdf

3. Brasil. Ministério da Saúde. Banco de Dados do Sistema Único de Saúde (DATASUS). Informações de Saúde. Epidemiologia e morbidade [Internet]. Brasília: MS; 2016 [citado 2016 jun. 9]. Disponível em: http://tabnet.datasus.gov.br

4. Global Initiative for Asthma. Global Strategy for Asthma Management and Prevention, updated 2017 [Internet]. Bethesda: GINA; 2017 [cited 2017 May 1]. Available from: http://ginasthma.org/2017-gina-report-global-strategy-for-asthma-management-and-prevention/

5. Bandura A. On the functional properties of perceived self-efficacy revisited. J Manag. [Internet]. 2012 [cited 2016 June 9];31(1):9-44. Available from: http://journals.sagepub.com/doi/pdf/10.1177/0149206311410606

6. Rajabi R, Forozy M, Fuladvandi M, Eslami H, Asadabady A. The effect of family-centered empowerment model on the knowledge, attitudes and self-efficacy of mothers of children with asthma. Iran Red Crescent Med J [Internet]. 2016 [cited 2017 May 10];5(4):41-50. Available from: https://www.ncbi.nlm.nih.gov/pmc/articles/PMC4005427/

7. Johnson MAJ, Javalkar K, Tilburg M, Haberman C, Rak E, Ferris ME. The relationship of transition readiness, self-efficacy, and adherence to preferred health learning method by youths with chronic conditions. J Pediatr Nurs. 2015;30(5):e83-90.

8. Gomes ALA, Ximenes LB, Mendes ERR, Teixeira OCM, Joventino ES, Javorski M. Translation and cultural adaptation of the self-efficacy and their child's level of asthma control scale: Brazilian version. Texto Contexto Enferm [Internet]. 2016 [cited 2017 Feb 20]; 25(3):e2950015. Available from: http://dx.doi.org/10.1590/0104-07072016002950015

9. Mendes EV. O cuidado das condições crônicas na atenção primária à saúde: o imperativo da consolidação da estratégia da saúde da família. Brasília: OPAS; 2012.

10. Sociedade Brasileira de Pneumologia e Tisiologia. Diretrizes da para o manejo da asma. J Bras Pneumol. 2012;38(1 Supl):1-46.

11. Warren F, Seymour RB, Brunner HLR. The association between self-efficacy and hypertension self-care activities among African American adults. J Commun Health. 2012;37(1):15-24.

12. Instituto Brasileiro de Geografia e Estatística. Síntese de indicadores sociais. Uma análise das condições de vida da população brasileira [Internet]. Rio de Janeiro: IBGE; 2013 [citado 2016 mar. 12]. Disponível em: http://biblioteca.ibge.gov.br/visualizacao/livros/liv66777.pdf

13. Brasil. Ministério da Saúde; Conselho Nacional de Saúde. Resolução n. 466/2012, de 12 de dezembro de 2012. Dispõe sobre diretrizes e normas regulamentadoras sobre pesquisas envolvendo seres humanos [Internet]. Brasília: CNS; 2012 [citado 2017fev. 20]. Disponível em: http://conselho.saude.gov.br/resolucoes/2012/Reso466.pdf

14. Mohajjel AA, Hasankhani H, Gharemohammadlu R, Esmaeily M. Relation of patients self-efficacy with control of asthma symptoms. J Gorgan Uni Med Sci. 2013;15(2):70-6.

15. Akinbami LJ, Moorman JE, Bailey C, Zahran HS, King M, Johnson CA, et al. Trends in asthma prevalence, health care use, and mortality in the United States 2001-2010. NCHS Data Brief. 2012;(94):1-8.

16. Andrews AL, Teufel RJ, Basco Jr WT. Low rates of controller medication initiation and outpatient follow-up after emergency department visits for asthma. J Pediatr. 2012;160(2):325-30.

17. Carroll D, Wildhaber J, Brand PLP. Parent misperception of control in childhood/adolescent asthma: the room to breathe survey. Eur Respir J. 2012;39(1):90-6.

18. Zhao J, Shen K, Xiang L, Zhang G, Xie M, Bai J. The knowledge, attitudes and practices of parents of children with asthma in 29 cities of china: a multi-center study. BMC Pediatr [Internet]. 2013 [cited 2016 July 14];13:20. Available from: http://bmcpediatr.biomedcentral. com/articles/10.1186/1471-2431-13-20

19. Lochte L, Nielsen KG, Petersen PE, Platts-Mills TAE. Childhood asthma and physical activity: a systematic review with meta-analysis and Graphic Appraisal Tool for Epidemiology assessment. BMC Pediatr [Internet]. 2016 [cited 2016 July 20];16:50. Available from: https:// bmcpediatr.biomedcentral.com/articles/10.1186/s12887-016-0571-4

20. Page TF, Beck-Sague CM, Pinzon-Iregui MC, Cuddihy A, Tyler T, Forno E, et al. Asthma in underserved schoolchildren in Miami, Florida: results of a school- and community-based needs assessment. J Asthma. 2013;50(5):480-7.

21. Pinnock H, Parke HL, Panagioti M, Daines L, Pearce G, Epiphaniou E, et al. Systematic meta-review of supported self-management for asthma: a healthcare perspective. BMC Med [Internet]. 2017 [cited 2017 July 27];15:64. Available from: https://www.ncbi.nlm.nih.gov/ pmc/articles/PMC5356253/

22. Galland BC, Taylor BJ, Elder DE, Herbison P. Normal sleep patterns in infants and children: a systematic review of observational studies. Sleep Med Rev. 2012;16(3): 213-22.

23. Harrington H, Prado N, Barry S. Treating asthma patients. Dental Abstracts [Internet]. 2017 [cited 2017 May 8];62(2):91-3. Available from: https://doi.org/10.1016/j.denabs.2016.07.034

24. Comaru T, Pitrez PM, Friedrich FO, Silveira VD, Pinto LA. Free asthma medications reduces hospital admissions in Brazil (Free asthma drugs reduces hospitalizations in Brazil). Respir Med. 2016;121:21-25.

25. Cohen S, Berkman N, Avital A, Springer C, Kordoba L, Haklai Z, et al. Decline in asthma prevalence and severity in Israel over a 10-year period. Respiration. 2015;89(1):27-32. 